\title{
Exploring Relationships Between Self-Efficacy and Self-Regulated Learning Strategies of English Language Learners in a College Setting
}

\author{
Daeyeoul Lee \\ Matthew Allen \\ Lixia Cheng \\ Sunnie Watson \\ William Watson \\ Purdue University, USA
}

\begin{abstract}
This study investigated the relationships between self-efficacy and self-regulated learning (SRL) strategies of English language learners (ELLs) in a college setting from a social cognitive perspective in order to understand how to better support international. Participants in this study were 117 ELL college students who enrolled in an English language course at a Midwestern university. The results of simple linear regression analysis showed that ELL college students' self-efficacy significantly predicted their use of SRL strategies. In addition, the results of a oneway ANOVA indicated a statistically significant difference in the use of SRL strategies between ELL college students who had high self-efficacy and those who had low self-efficacy. Based on study results, implications and future research directions are discussed.
\end{abstract}

Keywords: English language learner, self-efficacy, self-regulated learning, social cognitive perspective, student success 


\section{INTRODUCTION}

Many students face academic challenges when they enter college because they do not understand how to be effective learners or they are not aware of which learning strategies will be most effective for them in their studies (Rachal et al., 2007). International students studying at institutes of higher education (IHE) in Englishspeaking countries, most of whom are English language learners (ELLs), face a distinct set of learning challenges that make the success of these students more difficult. ELL students must manage complex interactions of academic, cultural, institutional, linguistic, personal, and social factors, the specifics of which depend on their background and their current higher educational context (Burns, 1991; Harklau, 2000; Jackson, 2017; Spack, 1997; Sun \& Chen, 1997). Not surprisingly, one of the major questions that arises is how to better support the success of international ELLs as they transition to college studies. There does not seem to be a simple answer. For instance, in a study of how international students adjust to university studies in the U.K., the researchers concluded that "personal, pedagogical and psychological factors are as important as organizational and social cultures in influencing students' adaptation, and ultimate success" (Gu et al., 2010, p. 20).

Self-regulated learning (SRL) has been identified as an important factor positively influencing students' academic success in college settings (Kitsantas et al., 2008). SRL generally refers to the "process whereby students activate and sustain cognitions, behaviors and affects, which are systematically oriented toward attainment of their goals" (Schunk \& Zimmerman, 1994, p. 309). However, SRL is still an underdeveloped concept in research on second language (L2) learning. While studies have examined SRL with technology such as through technology enhancement (Zheng et al., 2016), online learning (Shyr \& Chen, 2018), and nonclassroom language learning such as through YouTube (Wang \& Chen, 2020), less research has focused on facilitating SRL growth in the traditional college classroom. This might be attributed to the lack of research findings on factors promoting self-regulatory processes and the relationships between variables that predict language achievements (Onoda, 2014). Most proposed SRL interventions have mainly focused on SRL strategies for reading comprehension of English as a foreign language (e.g., Maftoon \& Tasnimi, 2014; Nejabati, 2015), underestimating the motivational component of SRL (Allen, 2013). In fact, motivational beliefs — including self-efficacy — play a vital role in self-regulation processes (Pintrich, 1999; Schunk \& Zimmerman, 1998). As a result, relatively little is known about how to promote SRL for ELLs in university classrooms, and given the recognized critical nature of SRL to student success, this is a significant gap in the literature for improving the success of international students.

L2 researchers have recently proposed several conceptual frameworks that integrate SRL theory into L2 contexts. For example, Oxford (2017) has proposed an enhanced Strategic Self-Regulation Model based on literature on SRL and motivation. Although this model includes an element of self-efficacy, it could not clearly explain how ELL students' self-efficacy is related to their use of SRL 
strategies. In fact, exploring this relationship is crucial since it could provide L2 educators and scholars with new insight into how to support ELL students' selfregulation in the classroom, thus improving the likelihood of their success in higher education. For instance, in general education settings, Zimmerman et al. (1996) suggested asking students to rate their self-efficacy beliefs after studying as this activity promotes self-monitoring and awareness of which goals were achieved. However, there is a dearth of empirical evidence of the relationships between self-efficacy and SRL strategies of ELL college students, a gap that undermines current approaches to facilitating the success of international students in English-speaking IHE.

The purpose of this study was to investigate the relationships between ELL college students' self-efficacy and their use of SRL strategies from a social cognitive perspective. The present study explored the applicability of using a social cognitive model of SRL (Zimmerman, 1989) in L2 areas, which could offer a foundation for the development of new conceptual frameworks or interventions to support L2 learning from a perspective of self-regulation.

\section{LITERATURE REVIEW}

\section{Self-Efficacy and Self-Regulated Learning Strategies}

Self-efficacy refers to "beliefs in one's capabilities to organize and execute courses of action required to produce given attainments" (Bandura, 1997, p. 3). Students' self-efficacy beliefs significantly affect their academic performance. Students with low self-efficacy beliefs are more likely to give up tasks when they face challenges; students with high self-efficacy are more likely to participate in tasks (Schunk, 1990). A wealth of studies identifies self-efficacy as a significant predictor of academic achievement (Ayllón et al., 2019; Honicke \& Broadbent, 2016; Sawtelle et al., 2012).

SRL is one of the key factors in students' success in academic settings (Zimmerman, 2002). Students who have high SRL skills demonstrate better academic performances than those having low SRL skills (Wolters \& Pintrich, 1998; Zimmerman, 2002; Zimmerman \& Bandura, 1994). Self-regulated learners use a variety of metacognitive, motivational, and behavioral regulation strategies (Simons \& Beukhof, 1987; Weinstein \& Mayer, 1986; Zimmerman, 2001). They are "proactive learners who incorporate various self-regulation processes (e.g., goal setting, self-observation, self-evaluation) with task strategies (e.g., study, time management, and organizational strategies) and self-motivational beliefs (e.g., self-efficacy, intrinsic interest)" (Cleary \& Zimmerman, 2004, p. 538).

Research in college settings has established the positive impact of selfregulation on students' academic success. For example, results of a survey of 243 undergraduate students showed that students' self-efficacy and time management predicted their second-semester GPA (Kitsantas et al., 2008). The relationship of SRL to academic success is important because students face many academic challenges in college. Rachal et al. (2007) found that, regardless of their academic classification, 485 undergraduate students reported on the Learning Needs 
Questionnaire that they had difficulties with their learning in diverse areas, including writing, executive study skills, note taking, and planning and organizing. In addition, many students enter college with a high level of selfefficacy based on their experiences of getting high scores with little effort in secondary school. However, students' self-efficacy decreases when they repeatedly experience poor academic performance (Hofer et al., 1998).

\section{Self-Efficacy and Self-Regulated Learning in the Context of Second Language Learning}

International students who learned English as an additional language must contend with a complex set of learning issues when they study in higher education settings (Andrade et al., 2014). Research has upended the assumption that students studying abroad for short- or long-term sojourns will automatically be immersed in rich language and cultural learning environments (Berg et al., 2012; Jackson, 2017). Furthermore, many universities and colleges do not provide appropriate and adequate support for international ELL college students, and these students often have difficulty adjusting to college in a foreign country (Andrade, 2006, 2009; Archer et al., 1998; Befus, 1988; Benzie, 2010). For instance, writing and composition studies have long noted the challenges faced by ELL studies in these language-intensive literacy courses and in writing work across content-area courses (e.g., Leki, 1995, 2017; Zamel, 1995). Part of the difficulty in addressing this situation is that the discussion is often framed in terms of ELL students' deficits in L2 proficiency based on unrealistic and unfair expectations of native proficiency in a second language, and a failure to recognize other cognitive, social, and cultural factors at play (Benzie, 2010). For instance, in their qualitative study with 10 Chinese students, Sun and Chen (1997) discovered through in-depth interviews that the students encountered difficulties in language proficiency, cultural awareness, and academic achievement.

To address these complex challenges, it is important for instructors and administrators to understand ELL college students' SRL in the context of L2. Learning strategies have been a popular topic in L2 language research for decades (e.g., Oxford, 1992, 2003), but only recently has there been an important shift in the L2 strategic framework from language learning strategies to include the concept of SRL (e.g. Andrade \& Evans, 2012-), due to several problems identified in the L2 literature (Rose, 2012). For example, L2 research has suffered from weak theoretical foundations in the learning strategies applicable to language studies. The theoretical foundations constructed thus far tend to be general and undefined (Tseng et al., 2006). In addition, the questionnaires developed to measure language learning strategies are unreliable and inaccurate (Dörnyei, 2005).

With this shift of the L2 strategic frameworks, researchers who have applied SRL in L2 contexts have found a positive relationship between SRL strategies and language performances of ELL college students (Mirhassani et al., 2007; Zarei \& Hatami, 2012). Specifically, several studies have found that the use of SRL strategies positively affects ELL college students' reading comprehension 
(Maftoon \& Tasnimi, 2014; Nejabati, 2015), listening achievement (Ateia, 2016; Nasrollahi-Mouziraji, 2016), writing performances (Soureshjani, 2011), and speaking performances (Aregu, 2013). In addition, self-efficacy is a strong predictor of performance in L2 contexts as identified in a review study investigating empirical research studies published from 2003 to 2012 (Raoofi et al., 2012). Therefore, SRL strategies and self-efficacy are vital factors that positively affect L2 learners.

\section{The Relationships Between Self-Efficacy and Self-Regulated Learning Strategies}

While different models of SRL (e.g., Pintrich, 2000; Zimmerman, 1989) have been adopted for research in L2 contexts, social cognitive models of SRL have recently received attention from L2 researchers (e.g., Nasrollahi-Mouziraji, 2016; Zarei et al., 2016). In a social cognitive model of SRL, the self-regulatory process is viewed as a triadic relationship between personal variables such as selfefficacy, behavioral variables such as the use of SRL strategies, and environmental variables such as feedback (Zimmerman, 1989). From a social cognitive perspective, self-efficacy is a key component affecting SRL processes (Zimmerman, 1989). The importance of the role of self-efficacy in self-regulatory processes is also shown in Zimmerman's (2000) SRL model, developed from a social cognitive perspective. According to Zimmerman (2000), the first phase of SRL processes starts with students' self-efficacy along with the use of goal setting and strategic planning.

Previous studies conducted in general academic settings have revealed that there are positive relationships between self-efficacy and the use of SRL strategies (Pintrich, 1999; Pintrich \& De Groot, 1990; Yusuf, 2011). For example, Pintrich (1999) found that there was a positive correlation between self-efficacy and SRL strategies including rehearsal, elaboration, and organization strategies for both middle school students and college students. Based on the study findings, Pintrich (1999) concluded that self-efficacy promotes and sustains SRL processes. Therefore, students who have high self-efficacy, characterized by being more persistent and hard-working and managing their emotions effectively, tend to use more SRL strategies than those who have low self-efficacy (Zimmerman, 2000). These relationships offer valuable insight into how to better support students' SRL. For example, Zimmerman et al. (1996) suggested asking students to rate their self-efficacy beliefs after studying because this activity promotes SRL strategies of self-monitoring and awareness of which goals were achieved.

Social cognitive models of SRL could explain variables affecting SRL processes and relationships between variables in L2 learning contexts. Most L2 studies on SRL employing social cognitive models of SRL have underestimated these relationships and only focused on the effects of SRL strategies on language achievement (e.g., Zarei et al., 2016). These might be attributed to limited understanding of social cognitive models of SRL in the L2 area. A few studies have examined the relationships. For example, Onoda (2014) investigated the interrelationships of self-efficacy, effort regulation strategies, and English 
vocabulary skills of college students majoring in English at a private Japanese university. Through structural equation modeling, the results of a survey of 235 Japanese college students indicated that self-efficacy significantly predicted use of effort regulation, which in turn affected the development of L2 vocabulary skills. Onoda's (2014) study contributed to the understanding of the relationships between self-efficacy and the use of SRL strategies in L2 learning settings. However, this study only focused on an effort regulation strategy and study samples were limited to ELL college students in their home country.

Despite an increasing number of international students in the United States (Institute of International Education [IIE], 2016), there is still limited understanding among educators, scholars, families, and other stakeholders about the relationship between self-efficacy and SRL strategies for international students. In order to effectively support the SRL of international students who are ELLs studying in a native English-speaking country, there is a need to investigate self-efficacy, other SRL strategies, and the relationships between them in U.S. university settings. This study employed Zimmerman's (1989) social cognitive model of SRL to investigate the relationships between self-efficacy and use of SRL strategies by ELL college students. This study addressed the following research question with two research hypotheses:

Are there relationships between ELL college students' self-efficacy and their use of SRL strategies?

$\mathrm{H}_{1}$ : Self-efficacy will significantly predict the use of SRL strategies of ELL college students.

$\mathrm{H}_{2}$ : There will be a significant difference in the use of SRL strategies between ELL college students with high self-efficacy and those with low self-efficacy.

\section{METHODS}

\section{Settings and Participants}

This study took place at a large Midwestern university in the United States with a sizable population of undergraduate international students, many of whom have learned English as second language. To help them successfully adapt to the university, incoming international students with a qualifying score on their language proficiency exam participated in a bridge course that helps ELLs develop the academic, linguistic, and cultural competencies needed to succeed in college. This course consisted of 24 sections in the spring 2018 semester, with each section capped at 16 students.

A convenience sampling method was used to recruit participants from eight sections of this course in the spring semester of 2018. As it turned out, 117 undergraduate students from 21 countries voluntarily participated in this study, including 74 students (63.2\%) from mainland China, speaking Mandarin Chinese 
as their first language. There was not a distinct pattern in the number and percentage of students from each of the other 20 countries, and those other countries all had much smaller representation than China in the sample group of students who voluntarily participated in our study. For instance, only 7 students out of the total 117 survey respondents were from India, with their self-reported first language ranging from Bengali, Hindi, to Sindhi. To sum up, survey respondents' native country and native language were not controlled in our study which did not use an experimental design, even though these two questions were included in the survey delivered to our participants.

As with native country and native language, how our sample group broke down in terms of other demographic variables, such as age, sex, and major college, may not follow the same patterns of these same variables as the entire cohort of 349 students in the course. Vast majority of our participants (113, $96.6 \%)$ were aged $18-20$. Three other participants $(2.6 \%)$ were aged $21-23$. One last participant $(0.9 \%)$ was aged over 27 . Seventy-one participants $(60.7 \%)$ were males and $46(39.3 \%)$ were females. The participating students were studying in 10 different colleges. In regard to their background in English learning and cultural adaptation, 73 participants $(62.4 \%)$ had spent more than one year living in English-speaking countries.

\section{Instruments}

The Motivated Strategies for Learning Questionnaire (MSLQ) developed by Pintrich et al. (1991) was adapted to measure ELL college students' self-efficacy and the use of SRL strategies. The MSLQ was developed to assess college students' motivation and their use of learning strategies using a 7-point Likert scale from "not at all true of me" to "very true of me." The MSLQ has been widely used in L2 studies to measure students' self-efficacy and the use of SRL strategies (e.g., Onoda, 2014; Shi, 2018). The adapted version of the MSLQ included selfefficacy $(n=8)$ items and learning strategies $(n=50)$ items. Learning strategies items fall into one of two categories: cognitive and metacognitive strategies, or resource management strategies. Cognitive and metacognitive strategies were assessed by items that ask about rehearsal $(n=4)$, elaboration $(n=6)$, organization $(n=4)$, critical thinking $(n=5)$, and metacognitive self-regulation $(n=12)$. Resource management strategies were assessed by items that ask about time and study environment $(n=8)$, effort regulation $(n=4)$, peer learning $(n=3)$, and help seeking $(n=4)$. The items were slightly modified to fit with the course and help participants to better understand contexts. For example, the statement "When I take a test, I think about how poorly I am doing compared with other students" was modified to "When I take a quiz in [this class] (e.g., a reading or vocabulary quiz), I think about how poorly I am doing compared with other students." The reliability of the MSLQ as measured by the Cronbach's $\alpha$ value was .96 , suggesting high internal consistency of the MSLQ items. 


\section{Data Collection and Analysis}

Once we received approval from the Institutional Review Board (IRB), we asked instructors of all sections of the course for permission to invite their students to participate in the study. Instructors who agreed were given a link to the online survey, which they posted on the Blackboard Course Management System at the end of the spring 2018 semester. The survey was anonymous and voluntary. There was no compensation for students who completed the survey.

Data analysis was conducted using the SPSS statistical software program. Among the total 117 responses, 4 missing responses and 23 outliers were excluded from the subsequent data analysis. Therefore, a total of 90 responses were analyzed. A simple linear regression analysis was conducted to test hypothesis. (1) Self-efficacy will significantly predict the use of SRL strategies of ELL college students. In addition, one-way analysis of variance (ANOVA) was conducted to test hypothesis. (2) There will be a significant difference in the use of SRL strategies between ELL college students with high self-efficacy and those with low self-efficacy. All assumptions for linear regression and one-way ANOVA were checked and represented in the following section.

\section{RESULTS}

\section{The Results of Simple Linear Regression Analysis}

Prior to conducting simple linear regression analysis, all assumptions were checked. First, scatterplots showed a linear relationship between self-efficacy and each SRL strategy. Second, the results of the Shapiro-Wilks test showed that the residuals are normally distributed $(p>.05)$. Lastly, the result of the BreuschPagan test (Breusch \& Pagan, 1979) showed that there was homoscedasticity $(p<.05)$. Therefore, weighted least squares (WLS) where "each case is weighted by a function of its variance" (Field, 2013, p. 222) was utilized to address homoscedasticity.

The simple linear regression model was statistically significant $(F(1,88)=$ $35.47, p<.01)$ and indicated that self-efficacy accounted for approximately $29 \%$ of the variation of the use of SRL strategies $\left(R^{2}=.29\right)$. Self-efficacy significantly predicted SRL strategies $(\beta=.54, p<.05)$. In order to examine which SRL strategies are best predicted by self-efficacy, additional simple linear regression analyses were conducted. Due to the violation of the assumption of normality, effort regulation and help seeking were excluded in additional simple linear regression analyses. WLS was also used to address homoscedasticity. In addition, according to Bonferroni correction which "adjusts probability $(p)$ values because of the increased risk of type I error when making multiple statistical tests" (Armstrong, 2014, p. 502), the $p$ value was set as .007 (.05/7).

As shown in Table 1, self-efficacy significantly predicted rehearsal, elaboration, organization, critical thinking, metacognitive self-regulation, and time management. However, a simple linear regression model for self-efficacy and peer learning was not significant $(F(1,88)=3.03, p>.01)$. This result raised 
a question of whether peer learning significantly predicts self-efficacy based on Zimmerman's (1989) social cognitive model of SRL explaining bidirectional relationship between the use of SRL strategy and self-efficacy. Therefore, another simple linear regression analysis was additionally conducted. The result showed that peer learning was a significant predictor of self-efficacy $(\beta=.21, p<.05)$.

\section{Table 1: Results of Simple Linear Regression Analyses}

\begin{tabular}{llllll}
\hline Model & Variable & $\beta$ & $t$ & $R^{2}$ & $F$ \\
\hline 1 & Rehearsal & .45 & $4.73^{* *}$ & .20 & $22.33^{*}$ \\
2 & Elaboration & .60 & $6.96^{* *}$ & .35 & $48.30^{*}$ \\
3 & Organization & .41 & $4.19^{* *}$ & .17 & $17.57^{*}$ \\
4 & Critical thinking & .26 & $5.50^{* *}$ & .26 & $30.21^{*}$ \\
5 & Peer learning & .18 & 1.74 & .03 & 3.03 \\
6 & Metacognitive Self- & .49 & $5.20^{* *}$ & .24 & $27.08^{*}$ \\
7 & Regulation & & & & \\
7 & Time Management & .42 & $4.30^{* *}$ & .17 & $18.49^{*}$ \\
\hline$p<.01 ; * * p<.007$. & & & &
\end{tabular}

\section{The Results of One-Way ANOVA}

Based on self-efficacy scores, students were classified into three level groups according to percentile: the low self-efficacy group was below the 25th percentile; the medium self-efficacy group was between the 25th percentile and 75th percentile; the high self-efficacy group was above the 75th percentile. Prior to conducting a one-way ANOVA, all assumptions were checked. The assumption of normality was met by the results of the Shapiro-Wilks test $(p>.05)$. In addition, the Levene's test results showed that there is a homogeneity of variances $(p>.05)$.

The results of the one-way ANOVA showed that there was a statistically significant difference in the use of SRL strategies between ELL college students who had high self-efficacy beliefs $(M=6.19, \mathrm{SD}=.57)$ and those who had low self-efficacy beliefs $(M=4.32, \mathrm{SD}=.37) ;(F(1,45)=20.92, p<.05)$. In order to identify differences in sub-SRL strategies between the two groups, additional oneway ANOVA analyses with Bonferroni correction were conducted. All assumptions for one-way ANOVA were checked. Due to the violations of homogeneity of variances, elaboration, organization, and critical thinking were excluded and three sub-SRL strategies were analyzed: rehearsal, metacognitive self-regulation, and time management. According to the Bonferroni correction, the $p$ value was set as $.016(.05 / 3)$. As shown in Table 2, statistically significant differences between the two groups were identified in all of three SRL strategies: rehearsal, metacognitive self-regulation, and time management. 
Table 2: Results of One-way ANOVA on SRL Strategies by Self-Efficacy Levels

\begin{tabular}{lrrrrr}
\hline Variable & DF & \multicolumn{1}{c}{ SS } & \multicolumn{1}{c}{ MS } & \multicolumn{1}{l}{$F$} & $p$ \\
\hline SRL & 1 & 4.97 & 4.97 & 20.92 & $.00^{*}$ \\
Between & 45 & 10.69 & .238 & & \\
Within & 46 & 15.67 & & & \\
$\quad$ Total & & & & & \\
R & 1 & 9.82 & 9.82 & 13.22 & $.00^{*}$ \\
Between & 45 & 33.41 & .68 & & \\
Within & 46 & 43.23 & & & \\
Total & & & & & \\
META & 1 & 5.40 & 14.18 & 18.46 & $.00^{*}$ \\
Between & 45 & 13.16 & .46 & & \\
Within & 45 & 18.55 & & & \\
Total & & & & & \\
TIME & 1 & 2.79 & 7.07 & 10.82 & $.00^{*}$ \\
Between & 45 & 11.62 & .80 & & \\
Within & 46 & 14.42 & & & \\
Total & & & &
\end{tabular}

$* p<.016$.

Note: $\mathrm{SRL}=$ self-regulated learning strategy, $\mathrm{R}=$ rehearsal, META $=$ metacognitive self-regulation, TIME $=$ time management.

\section{DISCUSSION}

This study investigated the relationships between self-efficacy and the use of SRL strategies of ELL college students from a social cognitive perspective. Few studies have examined the relationships between self-efficacy and SRL strategies in L2 settings where international students from different countries learn English as a second language; consequently, there is a scarcity of teaching practice about how to support and promote SRL of ELL college students in the classroom. 


\section{Are There Relationships Between ELL College Students' Self-Efficacy and Their Use of SRL Strategies?}

The findings of this study indicated that a positive relationship between selfefficacy and use of SRL strategies, which has been widely identified in K-12 and higher education settings, could be applied in the context of L2 studied here. They contributed to a better understanding of the relationship between self-efficacy and SRL strategies of international students who study as ELLs in a US university setting. In addition, it was identified that self-efficacy could be a personal variable, and SRL strategy could be a behavioral variable in the self-regulatory process in L2 settings within Zimmerman's (1989) social cognitive model of SRL.

The result of linear regression analysis showed that ELL college students' self-efficacy significantly predicted their use of SRL strategies in the context of L2 studied here. These findings are consistent with a previous study that found a positive relationship between self-efficacy beliefs and the use of SRL strategy by ELL college students (Onoda, 2014). However, while Onoda (2014) only focused on effort regulation strategy, the present study examined overall SRL strategies as well as sub-SRL strategies. The findings of this study showed that ELL college students' self-efficacy significantly predicted rehearsal, elaboration, organization, critical thinking, metacognitive self-regulation, and time management strategies. Therefore, the findings of this study provide broader insights into the relationship between self-efficacy beliefs and the SRL strategies of ELL college students. They support Pintrich's (1999) assertation that learners' self-efficacy promotes their SRL behaviors. Considering that ELL college students' self-efficacy positively affects their use of SRL strategies, it is important for instructors to develop their students' self-efficacy in L2 settings.

However, ELL college students' self-efficacy was not a significant predictor for their use of peer learning strategy in this study. Literature could not fully explain this result due to the lack of empirical evidence of a predictive power of self-efficacy for peer learning strategy in L2 settings. However, according to Zimmerman's (1989) social cognitive model of SRL, the relationship between behavioral factors and personal factors is bidirectional. This is supported by the result of another simple linear regression analysis showing that ELL college students' peer learning significantly predicted their self-efficacy. Therefore, ELL college students' peer learning played a role in enhancing their self-efficacy beliefs in this study.

ELL college students with high self-efficacy in this study had significantly higher scores in the use of SRL strategies than those with low self-efficacy. Specifically, there was a statistically significant difference between the two groups on the following SRL strategies: rehearsal, metacognitive regulation, and time management. This offers empirical evidence of the key role that ELL college students' self-efficacy beliefs play in their self-regulation processes and further supports the relationship between self-efficacy and the use of SRL strategies. These findings also support assertions that "self-efficacy operates during all phases of self-regulation" (Schunk \& Ertmer, 2000, p. 634), and positive selfefficacy beliefs can improve self-regulatory behaviors (Pintrich, 1999). 


\section{Implications for Practice and Research}

The findings of this study have implications for practice and research. SRL and self-efficacy have been shown to be vital to student success in higher education. The relationships between self-efficacy and SRL strategies found in the present study indicate that instructors and L2 researchers should help ELL college students develop their self-efficacy. Bandura (1977) suggested four major sources of self-efficacy beliefs: performance accomplishments, vicarious experience, verbal persuasion, and physiological and affective states. While these main sources of self-efficacy have been widely applied in interventions to develop self-efficacy in college settings (Bartimote-Aufflick et al., 2016), empirical studies on them are lacking as identified in a review study on self-efficacy in L2 contexts (Raoofi et al., 2012). Therefore, instructors or L2 researchers need to examine if teaching strategies identified in a recent review study by BartimoteAufflick et al. (2016) as effective in improving college students' self-efficacy could be applied into L2 settings. For example, they could use the following effective teaching strategy that would be applicable in any discipline: "if using an oral presentation as part of your assessment schedule, arrange a model presentation for students to view either live, or as a video" (Bartimote-Aufflick et al., 2016, p. 1930). In addition, as Raoofi et al. (2012) suggested in their review study, instructors could provide ELL students with opportunities to observe peers who successfully completed tasks for vicarious experience. Given that ELL students' peer learning significantly predicted their self-efficacy, instructors could also utilize collaboration tools such as wiki (Su et al., 2018) to help students employ peer learning strategy, which ultimately enhances self-efficacy.

An important implication for IHE is the need to establish systems that better support their ELL students. Research on how to effectively meet the specific needs of international students, most of whom are ELL students, has not sufficiently progressed (Brunsting et al., 2018) and further information is needed on specifically what academic activities most benefit these students (Kovtun, 2011). A recent case study confirmed that ELL students perceived instruction on SRL strategies as important to their success and accordingly adopted the behaviors and strategies that they were taught (Watson, Watson, Fehrman, Yu, \& Janakiraman, 2020). Integrating instruction on SRL strategies as part of required ELL instruction, such as was done in this case, could be an effective approach. As the numbers of undergraduate international students enrolled in American IHEs has greatly increased in recent years (IIE, 2016), these organizations have additional responsibility to promote ESL students' success, and this study indicates that facilitating their understanding and use of SRL strategies is an important consideration and one that should rise above the responsibility of individual instructors and instead be a focus at the IHE system level. Or as Brunsting, Zachry, and Takeuchi (2018) put it: "It is critical for college and university personnel, whether administration, faculty, or campus life, to appreciate the unique challenges facing undergraduate international students," (p. 29), and as this study has shown, understanding how to effectively improve their SRL skills is an important consideration. 


\section{LIMITATIONS AND FUTURE RESEARCH}

This study has some limitations. First, data were collected from a self-reported questionnaire which depends on ELL college students' self-assessment on their self-efficacy and ability to use SRL strategy. Although MSLQ has been increasingly used in L2 studies with reliability and applicability identified in L2 settings (e.g., Huang, 2008), qualitative data such as interviews or course artifacts could support robustness of findings of this study. Such research methods could be helpful to investigate why ELL college students' self-efficacy significantly predicted not all SRL strategies but some of them. Second, the sample is limited to a single large Midwestern university. There are significant gaps in regard to meeting ELL student needs at IHEs in general, and how to best effectively teach SRL strategies specifically. Therefore, future research is strongly suggested to explore this topic in other university settings. Lastly, all SRL strategies could not be examined in this study due to the violations of assumptions. Future research should investigate differences in the use of other SRL strategies such as help seeking between ELL college students with high self-efficacy and those with low self-efficacy.

\section{CONCLUSION}

This study used Zimmerman's (1998) social cognitive model of SRL to examine the relationships between self-efficacy and use of SRL strategies by ELL college students, an important contribution to the research literature that has largely not addressed the relationships between them in U.S. university settings for ELL students. The findings indicated that ELL college students' self-efficacy significantly predicted their use of SRL strategy. Specifically, ELL college students' self-efficacy significantly predicted the following sub-SRL strategies: rehearsal, elaboration, organization, critical thinking, metacognitive selfregulation, and time management. In addition, there was a statistically significant difference in the use SRL strategies between ELL college students with high selfefficacy beliefs and those with low self-efficacy beliefs. Specifically, there was a statistically significant difference in the following sub-SRL strategies between the two groups: rehearsal, metacognitive self-regulation, and time management. This study provides empirical evidence of the relationship between self-efficacy and SRL strategies in L2 settings and the key role of ELL college students' selfefficacy in self-regulation processes.

\section{REFERENCES}

Allen, H. W. (2013). Self-regulatory strategies of foreign language learners: From the classroom to study abroad and beyond. In C. Kinginger (Ed.), Social and cultural aspects of language learning in study abroad (pp. 47-72). John Benjamins Publishing. 
Andrade, M. S. (2006). International students in English-speaking universities: Adjustment factors. Journal of Research in International Education, 5(2), 131-154. https://doi.org/10.1177/1475240906065589

Andrade, M. S. (2009). The effects of English language proficiency on adjustment to university life. International Multilingual Research Journal, 3(1), 16-34. https://doi.org/10.1080/19313150802668249

Andrade, M. S., \& Evans, N. W. (2012). Principles and practices for response in second language writing: Developing self-regulated learners. Routledge.

Andrade, M. S., Evans, N. W., \& Hartshorn, K. J. (2014). Linguistic support for non-native English speakers: Higher education practices in the United States. Journal of Student Affairs Research and Practice, 51(2), 207-221. https://doi.org/10.1515/jsarp-2014-0020

Archer, J., Ireland, J., Amos, S. L., Broad, H., \& Currid, L. (1998). Derivation of a homesickness scale. British Journal of Psychology, 89(2), 205-217. https://doi.org/10.1111/j.2044-8295.1998.tb02681.x

Aregu, B. B. (2013). Enhancing self-regulated learning in teaching spoken communication: Does it affect speaking efficacy and performance? Electronic Journal of Foreign Language Teaching, 10(1), 96-109.

Armstrong, R. A. (2014). When to use the Bonferroni correction. Ophthalmic and Physiological Optics, 34(5), 502-508. https://doi.org/10.1111/opo.12131

Ateia, S. A. H. E. (2016). The effect of self-regulatory strategies in enhancing listening skills and self-efficacy of EFL learners. Journal of Research in Curriculum, Instruction and Educational Technology, 2(2), 43-68. https://doi.org/10.12816/0028181

Ayllón, S., Alsina, Á., \& Colomer, J. (2019). Teachers' involvement and students' self-efficacy: Keys to achievement in higher education. PLOS ONE, 14(5), e0216865. https://doi.org/10.1371/journal.pone.0216865

Bandura, A. (1977). Self-efficacy: Toward a unifying theory of behavioral change. Psychological Review, 84(2), 191-215. https://doi.org/10.1037/ 0033-295x.84.2.191

Bandura, A. (1997). Self-efficacy: The exercise of control. W. H. Freeman.

Bartimote-Aufflick, K., Bridgeman, A., Walker, R., Sharma, M., \& Smith, L. (2016). The study, evaluation, and improvement of university student selfefficacy. Studies in Higher Education, 41(11), 1918-1942. https://doi.org/ 10.1080/03075079.2014.999319

Befus, C. P. (1988). A multilevel treatment approach for culture shock experienced by sojourners. International Journal of Intercultural Relations, 12(4), 381-400. https://doi.org/10.1016/0147-1767(88)90032-6

Benzie, H. J. (2010). Graduating as a 'native speaker': International students and English language proficiency in higher education. Higher Education Research \& Development, 29(4), 447-459. https://doi.org/10.1080/ 07294361003598824

Berg, M. V., Paige, R. M., \& Lou, K. H. (2012). Student learning abroad: What our students are learning, what they? Re not, and what we can do about it. Stylus Publishing. 
Breusch, T. S., \& Pagan, A. R. (1979). A simple test for heteroscedasticity and random coefficient variation. Econometrica: Journal of the Econometric Society, 47(5), 1287-1294. https://doi.org/10.2307/1911963

Brunsting, N. C., Smith, A. C., \& Zachry, C. E. (2018). An academic and cultural transition course for international students: Efficacy and socio-emotional outcomes. Journal of International Students, 8(4), 1497-1521. https://doi.org/10.32674/jis.v8i4.213

Brunsting, N. C., Zachry, C., \& Takeuchi, R. (2018). Predictors of undergraduate international student psychosocial adjustment to US universities: A systematic review from 2009-2018. International Journal of Intercultural Relations, 66, 22-33. https://doi.org/10.1016/j.ijintrel.2018.06.002

Burns, R. B. (1991). Study and stress among first year overseas students in an Australian university. Higher Education Research and Development, 10(1), 61-77. https://doi.org/10.1080/0729436910100106

Cleary, T. J., \& Zimmerman, B. J. (2004). Self-regulation empowerment program: A school-based program to enhance self-regulated and self-motivated cycles of student learning. Psychology in the Schools, 41(5), 537-550. https://doi.org/10.1002/pits.10177

Dörnyei, Z. (2005). The psychology of the language learner: Individual differences in second language acquisition. Lawrence Erlbaum.

Field, A. (2013). Discovering statistics using IBM SPSS statistics (4th ed.). SAGE.

Gu, Q., Schweisfurth, M., \& Day, C. (2010). Learning and growing in a 'foreign' context: Intercultural experiences of international students. Compare: $A$ Journal of Comparative and International Education, 40(1), 7-23. https://doi.org/10.1080/03057920903115983

Harklau, L. (2000). From the "Good Kids" to the "Worst": Representations of English Language learners across educational settings. TESOL Quarterly, 34(1), 35-67. https://doi.org/10.2307/3588096

Hofer, B. K., Yu, S. L., \& Pintrich, P. R. (1998). Teaching college students to be self-regulated learners. In D. H. Shunk \& B. J. Zimmerman (Eds), Selfregulated learning: From teaching to self-reflective practice (pp. 57-85). Guilford Press.

Honicke, T., \& Broadbent, J. (2016). The influence of academic self-efficacy on academic performance: A systematic review. Educational Research Review, 17, 63-84. https://doi.org/10.1016/j.edurev.2015.11.002

Huang, S. C. (2008). Assessing motivation and learning strategies using the Motivated Strategies for Learning Questionnaire in a foreign language learning context. Social Behavior and Personality: An International Journal, 36(4), 529-534. https://doi.org/10.2224/sbp.2008.36.4.529

Institute of International Education. (2016). International student enrollment trends, 1948/49-2015/16. Open doors report on international educational exchange. http://www.iie.org/opendoors

Jackson, J. (2017). Intervening in the intercultural learning of L2 study abroad students: From research to practice. Language Teaching, 51(3), 365-382. https://doi.org/10.1017/s0261444816000392 
Kitsantas, A., Winsler, A., \& Huie, F. (2008). Self-regulation and ability predictors of academic success during college: A predictive validity study. Journal of Advanced Academics, 20(1), 42-68. https://doi.org/10.4219/jaa2008-867

Kovtun, O. (2011). International student adaptation to a US college: A mixed methods exploration of the impact of a specialized first-year course at a large Midwestern institution. Journal of Student Affairs Research and Practice, 48(3), 349-366. https://doi.org/10.2202/1949-6605.6336

Leki, I. (1995). Coping strategies of ESL students in writing tasks across the curriculum. TESOL Quarterly, 29(2), 235-260. https://doi.org/10.2307/ 3587624

Leki, I. (2017). Undergraduates in a second language: Challenges and complexities of academic literacy development. Routledge.

Maftoon, P., \& Tasnimi, M. (2014). Using self-regulation to enhance EFL learners' reading comprehension. Journal of Language Teaching and Research, 5(4), 844-855. https://doi.org/10.4304/jltr.5.4.844-855

Mirhassani, A., Akbari, R., \& Dehghan, M. (2007). The relationship between Iranian EFL learners' goal-oriented and self-regulated learning and their language proficiency. Journal of Teaching English Language and Literature Society of Iran, 1(2), 1-15.

Nasrollahi-Mouziraji, A. (2016). Self-regulated learning strategies, achievement goals and listening achievement of Iranian EFL learners. International Journal of Foreign Language Teaching and Research, 4(16), 11-24.

Nejabati, N. (2015). The effects of teaching self-regulated learning strategies on EFL students' reading comprehension. Journal of Language Teaching and Research, 6(6), 1343-1348. https://doi.org/10.17507/jltr.0606.23

Onoda, S. (2014). Examining the relationships between self-efficacy, effort regulation strategy use, and English vocabulary skills. Studies in Self-Access Learning Journal, 5(4), 357-373. https://doi.org/10.37237/050404

Oxford, R. L. (1992). Research on second language learning strategies. Annual Review of Applied Linguistics, 13, 174-187. https://doi.org/10.1017/ s0267190500002452

Oxford, R. L. (2003). Language learning styles and strategies: Concepts and relationships. International Review of Applied Linguistics in Language Teaching, 41(4), 271-278. https://doi.org/10.1515/iral.2003.012

Oxford, R. L. (2017). Teaching and researching language learning strategies: Selfregulation in context (2nd ed.). Taylor \& Francis.

Pintrich, P. R. (1999). The role of motivation in promoting and sustaining selfregulated learning. International Journal of Educational Research, 31(6), 459-470. https://doi.org/10.1016/s0883-0355(99)00015-4

Pintrich, P. R. (2000). The role of goal orientation in self-regulated learning. In M. Boekaerts, P. R. Pintrich, \& M. Zeidner (Eds.), Handbook of selfregulation (pp. 451-502). Academic.

Pintrich, P. R., \& De Groot, E. V. (1990). Motivational and self-regulated learning components of classroom academic performance. Journal of educational psychology, 82(1), 33. https://doi.org/10.1037/0022-0663.82.1.33 
Pintrich, P. R., Smith, D. A. F., Garcia, T., \& McKeachie, W. J. (1991). A manual for the use of the Motivated Strategies for Learning Questionnaire (MSLQ). The University of Michigan.

Rachal, K. C., Daigle, S., \& Rachal, W. S. (2007). Learning problems reported by college students: Are they using learning strategies? Journal of Instructional Psychology, 34(4), 191-199.

Raoofi, S., Tan, B. H., \& Chan, S. H. (2012). Self-efficacy in second/foreign language learning contexts. English Language Teaching, 5(11), 60-73. https://doi.org/10.5539/elt.v5n11p60

Rose, H. (2012). Reconceptualizing strategic learning in the face of selfregulation: Throwing language learning strategies out with the bathwater. Applied Linguistics, 33(1), 92-98. https://doi.org/10.1093/applin/amr045

Sawtelle, V., Brewe, E., \& Kramer, L. H. (2012). Exploring the relationship between self-efficacy and retention in introductory physics. Journal of Research in Science Teaching, 49(9), 1096-1121. https://doi.org/10.1002/ tea. 21050

Schunk, D. H. (1990). Goal setting and self-efficacy during self-regulated learning. Educational Psychologist, 25(1), 71-86. https://doi.org/10.1207/ s15326985ep2501_6

Schunk, D. H., \& Ertmer, P. A. (2000). Self-regulation and academic learning self-efficacy enhancing interventions. In M. Boekaerts, P. Pintrich, \& M. Zeider (Eds.), Handbook of self-regulation (pp. 631-649). Academic Press.

Schunk, D. H., \& Zimmerman, B. J. (1994). Self-regulation of learning and performance: Issues and educational applications. Erlbaum.

Schunk, D. H., \& Zimmerman, B.J. (1998). Self-regulated learning: From teaching to self-reflective practice. Guilford Press.

Shi, H. (2018). Self-Efficacy Beliefs and Effective Instructional Strategies: US University English Learners' Perspective. International Journal of Teaching and Learning in Higher Education, 30(3), 477-496.

Shyr, W. J., \& Chen, C. H. (2018). Designing a technology-enhanced flipped learning system to facilitate students' self-regulation and performance. Journal of Computer Assisted Learning, 34(1), 53-62. https://doi.org/ $10.1111 /$ jcal.12213

Simons, P. R. J., \& Beukhof, G. (1987). Regulation of learning. SVO.

Soureshjani, K. (2011). Self-regulation and motivation reconsideration through Persian EFL learners' writing achievement. Journal of Research Humanities, $11,55-80$.

Spack, R. (1997). The rhetorical construction of multilingual students. TESOL Quarterly, 31(4), 765-774. https://doi.org/10.2307/3587759

Su, Y., Li, Y., Hu, H., \& Rosé, C. P. (2018). Exploring college English language learners' self and social regulation of learning during wiki-supported collaborative reading activities. International Journal of Computer-Supported Collaborative Learning, 13(1), 35-60. https://doi.org/10.1007/s11412-0189269-y 
Sun, W., \& Chen, G. (1997). Dimensions of difficulties mainland Chinese students encounter in the United States. Paper presented at the 6th International Conference on Cross-Cultural Communication, Tempe, Arizona.

Tseng, W. T., Dörnyei, Z., \& Schmitt, N. (2006). A new approach to assessing strategic learning: The case of self-regulation in vocabulary acquisition. Applied Linguistics, 27(1), 78-102. https://doi.org/10.1093/applin/ami046

Wang, H. C., \& Chen, C. W. Y. (2020). Learning English from YouTubers: English L2 learners' self-regulated language learning on YouTube. Innovation in Language Learning and Teaching, 14(4), 333-346. https://doi.org/10.1080/17501229.2019.1607356

Watson, W. R., Watson, S. L., Fehrman, S. E., Yu, J. H., \& Janakiraman, S. (2020). Examining international students' attitudinal learning in a higher education course on cultural and language learning. Journal of International Students, 10(3), 664-687. https://doi.org/10.32674/jis.v10i3.1083

Weinstein, C. E., \& Mayer, R. E. (1986). The teaching of learning strategies. In M. C. Wittrock (Ed.), Handbook of research on teaching (pp. 315-327). Macmillan.

Wolters, C. A., \& Pintrich, P. R. (1998). Contextual differences in student motivation and self-regulated learning in mathematics, English, and social studies classrooms. Instructional Science, 26(1), 27-47. https://doi.org/ 10.1007/978-94-017-2243-8_6

Yusuf, M. (2011). The impact of self-efficacy, achievement motivation, and selfregulated learning strategies on students' academic achievement. ProcediaSocial and Behavioral Sciences, 15, 2623-2626. https://doi.org/10.1016/ j.sbspro.2011.04.158

Zamel, V. (1995). Strangers in academia: The experiences of faculty and ESL students across the curriculum. College Composition and Communication, 46(4), 506-521. https://doi.org/10.2307/358325

Zarei, A. A., Esfandiari, R., \& Akbari, A. (2016). Self-regulated learning strategies as predictors of reading comprehension. English Language Teaching, 3(2), 42-29.

Zarei, A. A., \& Hatami, G. (2012). On the relationship between self-regulated learning components and L2 vocabulary knowledge and reading comprehension. Theory and Practice in Language Studies, 2(9), 1939-1944. https://doi.org/10.4304/tpls.2.9.1939-1944

Zheng, C., Liang, J. C., Yang, Y. F., \& Tsai, C. C. (2016). The relationship between Chinese university students' conceptions of language learning and their online self-regulation. System, 57, 66-78. https://doi.org/10.1016/ j.system.2016.01.005

Zimmerman, B. J. (1989). A social cognitive view of self-regulated academic learning. Journal of Educational Psychology, 81(3), 329-339. https://doi.org/10.1037/0022-0663.81.3.329

Zimmerman, B. J. (1998). Academic studing and the development of personal skill: A self-regulatory perspective. Educational psychologist, 33(2-3), 7386. https://doi.org/10.1080/00461520.1998.9653292 
Zimmerman, B. J. (2000). Self-efficacy: An essential motive to learn. Contemporary Educational Psychology, 25(1), 82-91. https://doi.org/ 10.1006/ceps.1999.1016

Zimmerman, B. J. (2001). Self-regulated learning. In N. J. Smelser \& P. B. Baltes (Eds.), International encyclopedia of the social \& behavioral sciences (pp. 13855-13859). Pergamon.

Zimmerman, B. J. (2002). Becoming a self-regulated learner: An overview. Theory into Practice, 41(2), 64-70. https://doi.org/10.1207/s15430421tip 4102 2

Zimmerman, B. J., \& Bandura, A. (1994). Impact of self-regulatory influences on writing course attainment. American Educational Research Journal, 31(4), 845-862. https://doi.org/10.3102/00028312031004845

Zimmerman, B. J., Bonner, S., \& Kovach, R. (1996). Developing self-regulated learners: Beyond achievement to self-efficacy. American Psychological Association.

DAEYEOUL LEE, PhD, is an instructional designer at Rider University. His research is centered on self-regulated learning, Massive Open Online Courses (MOOCs), online and blended learning, and engineering education. Email: dalee@rider.edu

MATTHEW ALLEN, PhD, is the assistant director of Curriculum and Instruction in the Purdue Language and Cultural Exchange (PLaCE) program at Purdue University. His scholarly interests include second language reading and writing, internationalization of higher education, and ESL curriculum and instruction. Email: mcallen@purdue.edu

LIXIA CHENG, PhD, is the assistant director of Testing in the Purdue Language and Cultural Exchange (PLaCE) program at Purdue University. Her major research interests lie in the areas of language assessment, second language acquisition, language program evaluation, and internationalization in higher education. Email: clixia@purdue.edu

SUNNIE WATSON, $\mathrm{PhD}$, is an associate professor in Learning Design and Technology at Purdue University. Her research focuses on the field of information age, learner-centered education, including attitude change instruction and information-age educational technology such as Massive Open Online Courses (MOOCs) and Personalized Integrated Educational System (PIES). Email: sunnieleewatson@purdue.edu

WILLIAM WATSON, $\mathrm{PhD}$, is an associate professor in Learning Design and Technology at Purdue University. His research focuses on realizing a personalized learning paradigm, including through the design and leveraging of attitudinal learning and learning technology such as video games, virtual environments, digital badges, and learning management software. Email: brwatson@purdue.edu 